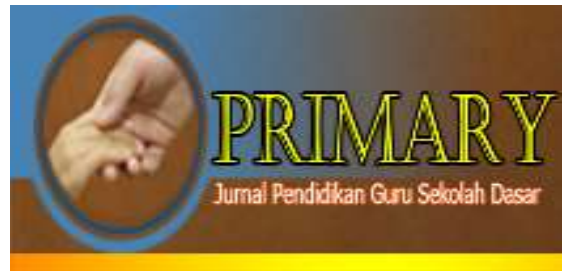
PRIMARY: JURNAL PENDIDIKAN GURU SEKOLAH DASAR
VOLUME 10 NOMOR 4 AGUSTUS 2021

ISSN : 2303-1514 | E-ISSN : 2598-5949

DOI : http://dx.doi.org/10.33578/jpfkip.v10i4.8492

https://primary.ejournal.unri.ac.id/index.php/JPFKIP

\title{
THE APPROACH OF EXAMPLES NON EXAMPLES METHOD WITH IMAGE MEDIA TO IMPROVE STUDENTS' WRITING SKILLS AT GRADE 2 OF SDN 022 HARAPAN BARU INDRAGIRI HILIR
}

\author{
Rodiyah \\ SDN 022 Harapan Baru Kecamatan Kempas, Indragiri Hilir, Indonesia \\ rodiahsaleh1412@gmail.com
PENDEKATAN METODE EXAMPLES NON EXAMPLES DENGAN MEDIA GAMBAR UNTUK MENINGKATKAN KETERAMPILAN MENULIS SISWA KELAS 2 SDN 022 HARAPAN BARU INDRAGIRI HILIR

\begin{tabular}{|c|c|}
\hline ARTICLE HISTORY & ABSTRACT \\
\hline $\begin{array}{l}\text { Submitted: } \\
13 \text { Juli } 2021 \\
13^{\text {th }} \text { July } 2021\end{array}$ & $\begin{array}{l}\text { Abstract: This form of research was a class action study conducted at grade } 2 \text { of SDN } 022 \\
\text { Harapan Baru Kabupaten Indragiri Hilir conducting in } 2 \text { cycles. Cycle I was planning and } \\
\text { Cycle II was actions using examples non examples approach with image media. The study } \\
\text { subject consisted of } 16 \text { grade } 2 \text { students. The research instruments were observation sheets and } \\
\text { daily test sheets. The purpose of the research was to improve the students' writing skills at } \\
\text { grade } 2 \text { of SDN } 022 \text { Harapan Baru. The results showed a significant improvement both in } \\
\text { terms of teacher's and students' learning activities as well as the students' writing skills. The } \\
\text { observation of teacher's activity in the initial data obtained a percentage of 55\%. Then, after } \\
\text { the reflection of learning, the percentage increased to } 85 \% \text { with good category. The } \\
\text { observation of students' activity in the initial data obtained a percentage of 53\% with fairly } \\
\text { good category. After the reflection of learning the percentage was } 92 \% \text { with good category. } \\
\text { After that, the results of the student's writing ability found an average score of } 60 \text { in the } \\
\text { preliminary data. After the reflection of learning, the average score was } 88 . \text { Based on the } \\
\text { presentation, it was concluded that examples non examples learning methods using image } \\
\text { media improved the students'writing skills at grade } 2 \text { of SDN } 022 \text { Harapan Baru. }\end{array}$ \\
\hline
\end{tabular}

Accepted:

04 Agustus 2021

$04^{\text {th }}$ August 2021

Keywords: writing skills, examples non examples images media

Abstrak: Bentuk penelitian ini adalah penelitian tindakan kelas yang dilakukan di kelas 2 SDN 022 Harapan Baru Kabupaten Indragiri Hulu dengan 2 siklus siklus I berupa perencanaan dan siklus II berupa tindakan menggunakan pendekatan examples non examples dengan media gambar. Subjek penelitian terdiri dari 16 orang siswa kelas 2, instrumen penelitian yaitu lembar observasi dan lembar ulangan harian. Tujuan penelitian yaitu untuk meningkatkan kemampuan menulis siswa kelas 2 SDN 022 Harapan Baru. Hasil penelitian menunjukkan terjadi peningkatan yang signifikan baik itu dari segi aktivitas kegiatan pembelajaran guru dan siswa maupun keterampilan menulis siswa. Untuk hasil observasi aktivitas guru pada data awal hanya sebesar 55\%, kemudian setelah refleksi pembelajaran didapat persentase sebesar $85 \%$ dengan kategori baik. Untuk hasil observasi aktivitas siswa pada data awal didapat persentase sebesar 53\% dengan kategori cukup baik, kemudian setelah dilakukan refleksi pembelajaran didapat persentase sebesar 92\% dengan kategori baik. Pada hasil kemampuan menulis siswa ditemukan data awal dengan nilai rata-rata sebesar 60 , kemudian setelah dilakukan refleksi pembelajaran didapat nilai rata-rata siswa berjumlah 88 , berdasarkan pemaparan tersebut dapat disimpulkan bahwa penerapan metode pembelajaran examples non examples menggunakan media gambar dapat meningkatkan keterampilan menulis siswa kelas 2 SDN 022 Harapan Baru.

Kata Kunci: keterampilan menulis, examples non examples media gambar CITATION

Rodiyah, R. (2021). The Approach of Examples Non Examples Method with Image Media to Improve Students' Writing Skills at Grade 2 of SDN 022 Harapan Baru Indragiri Hilir. Primary: Jurnal Pendidikan Guru Sekolah Dasar, 10 (4), 960-967. DOI: http://dx.doi.org/10.33578/jpfkip.v10i4.8492 


\section{PENDAHULUAN}

Kegiatan pembelajaran memiliki tujuan yang berguna untuk memperbaiki serta meningkatkan prestasi sswa serta mengembangkan kemampuan siswa dalam proses belajar. Salah satu hal yang sangat penting pada proses pembelajaran adalah kemampuan berbahasa bagi siswa agar siswa lebih mudah dalam berinteraksi dengan lingkungan sekitar. Kemampuan berbahasa tersebut dapat meliputi kemampuan berbicara, menulis, menyimak, dan membaca (Windarto, 2020). Hal itu sejalan dengan pendapat Mustikowati (2016) bahwa pada kegiatan pembelajaran bahasa Indonesia bagi siswa sekolah dasar yang menjadi dasarnya adalah keterampilan membaca dan menulis, karena hal tersebut merupakan dasar pelajaran pada kelas selanjutnya.

Salah satu aspek keterampilan berbahasa yang sangat penting peranannya dalam upaya melahirkan generasi masa depan yang cerdas, kritis, kreatif, dan berbudaya adalah keterampilan menulis, karena pada dasarnya kegiatan menulis tersebut juga melibatkan aspek bahasa lainnya yaitu membaca, dengan sejalannya kedua aspek tersebut maka anak akan lebih mudah memahami topik yang dipelajarinya serta dapat berkomunikasi dengan baik (Pratiwi, dkk, 2018). Dengan menguasai keterampilan menulis, peserta didik akan mampu mengekspresikan pikiran dan perasaannya secara cerdas sesuai konteks dan situasi pada saat dia sedang menulis. Keterampilan menulis juga melahirkan suatu tuturan atau ujaran yang komunikatif, jelas, runtut, mudah dipahami dan sistematis.Menulis merupakan suatu hal yang penting yang tidak bisa terlepas dari kegiatan pembelajaran, karena menulis termasuk dalam satu aplikasi keterampilan berbahasa (Hartati, 2006).

Berdasarkan data yang ditemukan peneliti Masih banyak siswa kelas 2 di SDN 022 Harapan Baru yang masih belum baik dalam keterampilan menulis ini, hal itu bisa saja karena merasa tidak memiliki bakat dalam menulis atau masih bingung dan tidak tahu apa yang ingin ditulis. Padahal kegiatan menulis memiliki banyak manfaat, diantaranya: (1) Dengan menulis maka potensi dan kemampuan diri siswa dapat dieksplorasi, dan (2) Dengan menulis siswa dapat melatih kemampuan dalam mengembangkan berbagai ide atau gagasan (Setiawan \& Mirnawati, 2017).

Berdasarkan fenomena diatas penelitian ini dilakukan untuk meningkatkan keterampilan menulis siswa kelas 2 SDN 022 Harapan Baru. Keterampilan menulis bagi siswa kelas 2 sekolah dasar tentunya harus menggunakan teknik atau cara yang tepat dan mudah dipahami oleh siswa, oleh karena itu guru harus pandai memilih metode pembelajaran yang sesuai dengan siswanya agar mampu mencapai tujuan dari pembelajaran tersebut. Salah satu metode pembelajaran yang dapat membuat pembelajaran yang kondusif, kreatif, efektif, dan menyenangkan bagi siswa adalah pembelajaran model examples non examples dengan menggunakan media gambar. Dengan penggunaan media gambar, siswa di kelas 2 SDN 022 Harapan Baru diarahkan untuk menulis suatu topik dan situasi yang nyata seperti benda, binatang, tumbuhan dan alam sekitar agar siswa lebih mudah memahami lingkungannya dengan menerapkan prinsip pemakaian bahasa dengan baik.

\section{KAJIAN TEORETIS \\ Pengertian Menulis}

Menulis merupakan suatu cara menuangkan atau melukiskan gambar atau simbol grafik yang menjelaskan suatu bahasa yang dapat dimengerti oleh seseorang agar orang lain dapat membaca langsung gambar atau simbol grafik tersebut (Febrina, 2017). Menulis merupakan kemampuan menggunakan pola-pola bahasa secara tertulis untuk mengungkapkan suatu gagasan atau pesan 
(Sobari, 2012). Menulis adalah proses menggambarkan suatu bahasa sehingga pesan yang disampaikan penulis dapat di pahami pembaca (Martavia, dkk, 2016). keterampilan menulis adalah kemampuan mengungkapkan gagasan, pendapat, dan perasaan kepada pihak lain dengan melalui bahasa tulis. Ketepatan pengungkapan gagasan harus didukung dengan ketepatan bahasa yang digunakan, kosakata dan gramatikal dan penggunaan ejaan (Bukhari, 2010). Hal itu sejalan dengan pendapat Nafiah (2017) menulis adalah sebuah proses, yaitu proses penuangan gagasan atau ide ke dalam bahasa tulis yang dalam praktik proses menulis diwujudkan dalam beberapa tahapan yang merupakan satu sistem yang lebih utuh.

Berdasarkan berbagai pendapat diatas dapat disimpulkan bahwa menulis merupakan suatu proses mendapatkan informasi atau suatu ide yang dituangkan dalam bentuk grafologi atau tulisan yang disampaikan penulis yang dapat dibaca dan dipahami.

\section{Pengertian metode examples non examples}

Metode example non example adalah salah satu metode pembelajaran yang menekankan pada kemampuan analisa siswa, umumnya metode ini biasa digunakan di kelas tinggi namun bisa juga diberikan pada siswa kelas rendah (Hamdayama, 2014). Karena dengan metode pembelajaran example non example dengan media gambar siswa menjadi lebih mudah untuk mengamati gambar secara langsung dan menuangkan apa yang dilihatnya tersebut ke dalam bentuk tulisan. Hal itu sejalan dengan pendapat Huda (2014) menjelaskan bahwa model example nonexample merupakan strategi pembelajaran yang menggunakan gambar sebagai media untuk menyampaikan materi pelajaran.

Gambar adalah salah satu alat yang jika digunakan dalam proses belajar mengajar dapat membantu dan melatih diri siswa mengembangkan pola pikirnya. Gambar juga mempunyai peranan penting dalam proses belajar mengajar, yakni untuk mempermudah dan membantu siswa dalam membangkitkan imajinasinya dalam belajar. Hal itu didukung oleh pendapat Lagandja (2008) pembelajaran Examples non Examples adalah model pembelajaran yang membelajarkan siswa terhadap permasalahan yang ada disekitarnya melalui proses analisis melalui gambar-gambar dan foto yang bermuatan kasus masalah.

Menurut Astuty (2012) Langkahlangkah Model Examples Non Examples sebagai berikut :(1) Guru mempersiap kan gambar-gambar sesuai dengan tujuan pembelajaran (2).Guru menempelkan gambar di papan atau ditayangkan melalui video zoom meeting, memberikan gambar pada peserta didik (3).Guru memberi petunjuk dan memberi kesempatan pada peserta didik untuk memperhatikan/menganalisa gam bar (4).Melalui diskusi kelompok, hasil diskusi dari analisa gambar tersebut dicatat pada kertas (5).Dari beberapa kelompok diberi kesempatan membacakan hasil diskusinya (6).Mulai dari ko mentar/hasil diskusi peserta didik, guru mulai menjelaskan materi sesuai tujuan yang ingin di capai (7).Kesimpulan.

Berdasarkan dari beberapa uraian diatas dapat disimpulkan bahwa metode pembelajaran examples non examples merupakan metode pembelajaran yang menggunakan gambar sebagai media pembelajarannya dan metode ini juga menekankan pada kemampuan analisa siswa sehingga siswa akan lebih mudah untuk memahami topic pembelajaran, diharapkan dengan diterapkannya metode ini dapat meningkatkan keterampilan menulis siswa.

\section{METODE PENELITIAN}

Penelitian ini adalah penelitian
tindakan kelas yang bertujuan untuk meningkatkan aktivitas siswa serta hasil belajar siswa dalam keterampilan menulis menggunakan media gambar. Pendekatan yang digunakan dalam penelitian ini adalah menggunakan metode example non example dengan gambar, tujuan penelitian ini adalah 
untuk meningkatkan keterampilan menulis siswa SDN 022 Harapan Baru. Penelitian dilakukan di SDN 022 Harapan Baru Kecamatan Kempas Kabupaten Indragiri Hilir dengan jumlah subjek penelitian secara keseluruhan terdiri dari 16 siswa, 10 siswa laki-laki dan 6 siswi perempuan. Penelitian dilakukan pada tanggal 10 Juni sampai tanggal 14 Juni 2021.

Penelitian tindakan kelas ini dilakukan dalam 2 siklus yaitu siklus I dan siklus II. Instrument dalam penelitian ini adalah observasi dan soal ulangan. Observasi dilakukan untuk melihat bagaimana aktivitas siswa dan guru saat kegiatan pembelajaran dikelas, sedangkan soal ulangan diberikan untuk melihat sejauh mana kemampuan atau keterampilan siswa dalam menulis setelah diberikannya tindakan berupa penerapan metode pembelajaran example non example dikelas.

\section{Teknik Analisis Data}

Untuk teknik analisis data pada penelitian ini menggunakan rumus persentase sebagai berikut:

$$
p=\frac{\mathrm{f}}{\mathrm{n}} \times 100 \%
$$

(Anas Sudijono, 2004)

Keterangan:

$\mathrm{f}=$ Frekuensi yang sedang dicari persentasenya

$\mathrm{n}=$ Number of Cases (jumlah frekuensi/banyaknya individu)

$\mathrm{P} \quad=$ Angka persentase

$100 \%=$ Bilangan Tetap

Tabel 1. Klasifikasi Pengukuran Persentase Hasil Observasi Aktivitas Guru dan Siswa

\begin{tabular}{ccc}
\hline No & Klasifikasi & Persentase $(\%)$ \\
\hline 1 & Baik & $67-100$ \\
2 & Cukup Baik & $34-66$ \\
3 & Kurang Baik & $0-33$ \\
\hline
\end{tabular}

(Arikunto, 2014).

Analisis hasil belajar siswa selama proses belajar dapat kita lihat dengan rumus peningkatan hasil belajar rata-rata kelas yaitu:

$$
p=\frac{\text { posrate }}{\text { baserate }} \times 100 \%
$$

(Zainal Aqib, 2009)

Keterangan:

$\mathrm{P} \quad=$ persentase peningkatan.

Posrate = nilai sesudah diberikan

tindakan.
Baserate = nilai sebelum tindakan.

\section{HASIL DAN PEMBAHASAN}

a. Observasi

Analisis kegiatan pembelajaran berupa aktivitas guru saat mengajar dilakukan sebanyak 2 siklus, berdasarkan data awal ditemukan hasil observasi aktivitas guru hanya 55\% hal itu masih dikategorikan cukup baik. Berikut adalah tabel aktivitas guru setelah refleksi pembelajaran:

Tabel 2. Persentase aktivitas guru siklus I dan siklus II

\begin{tabular}{llll}
\hline Siklus & Pertemuan & Persentase & kategori \\
\hline I & I & $55 \%$ & Cukup baik \\
& II & $65 \%$ & Cukup baik \\
II & III & $80 \%$ & Baik \\
& IV & $85 \%$ & Baik \\
\hline
\end{tabular}

Bersasarkan tabel di atas dapat dilihat bahwa pada pertemuan I siklus I aktivitas guru dalam kegiatan pembelajaran hanya sebesar
55\% dengan kategori cukup baik, kemudian pada pertemuan ke II didapat persentase sebesar $65 \%$ dengan kategori cukup baik, pada 
pertemuan ke III siklus II ditemukan data aktivitas guru sebesar $80 \%$ dengan kategori baik, pada pertemuan ke IV ditemukan data aktivitas guru sebesar $85 \%$ dengan kategori baik.
Hasil observasi analisis aktivitas kegiatan siswa dalam pembelajaran sebelum dilakukan refleksi pembelajaran dan sesudah dilakukan refleksi pembelajaran dapat kita lihat pada tabel berikut:

Tabel 3. Persentase aktivitas siswa siklus I dan siklus II

\begin{tabular}{llll}
\hline Siklus & Pertemuan & Persentase & kategori \\
\hline I & I & $53 \%$ & Cukup baik \\
& II & $60 \%$ & Cukup baik \\
II & III & $86 \%$ & Baik \\
& IV & $92 \%$ & Baik \\
\hline
\end{tabular}

Berdasarkan dari data di atas dapat dilihat bahwa persentase aktivitas siswa dari siklus I ke siklus II mengalami peningkatan yang cukup baik, pada siklus I pertemuan I didapat persentase aktivitas siswa dalam proses pembelajaran hanya sebesar $53 \%$ dengan kategori cukup baik, selanjutnya pada pertemuan ke II didapat persentase sebesar $60 \%$ dengan kategori cukup baik, kemudian pada siklus II pertemuan ke II didapat persentase sebesar $86 \%$ dengan kategori baik, dan pada pertemuan ke IV atau terakhir didapat persentase aktivitas belajar siswa sebanyak 92\% dengan kategori baik. Oleh karena itu dapat disimpulkan bahwa aktivitas siswa mengalami peningkatan yang signifikan dari data awal.

\section{b. Hasil belajar Menulis}

Data analisis hasil belajar siswa kelas 2 SDN 022 Harapan Baru Kecamatan Kempas Kabupaten Indragiri Hilir teridiri dari 2 Siklus, berikut data hasil belajar siswa dengan melakukan ulangan harian I dan ulangan harian II setelah dilakukan tindakan perbaikan pembelajaran:

Tabel 3. Hasil Belajar Keterampilan Menulis Siswa

\begin{tabular}{lllcc}
\hline No & Data & Rata-rata & \multicolumn{2}{c}{ Peningkatan } \\
& & & DA- UH 1 & DA-UH2 \\
\hline 1. & Data Awal & 60 & & \\
2. & Ulangan harian I & 80 & $13.3 \%$ & $14.6 \%$ \\
3. & Ulangan harian II & 88 & & \\
\hline
\end{tabular}

Berdasarkan tabel diatas dapat dilihat bahwa keterampilan menulis siswa kelas 2 SDN 022 Harapan Baru pada data awal nilai rata-rata hasil ulangan harian siswa sebesar 60 tentu saja nilai tersebut masih dibawah standar KKM , kemudian setelah dilakukan refleksi pembelajaran pada ulangan harian I didapat nilai rata-rata hasil belajar siswa berjumlah 80 terjadi peningkatan $13.3 \%$ dibanding dengan data awal, dan pada ulangan harian ke II nilai rata-rata hasil belajar siswa juga mengalami peningkatan dengan jumlah nilai rata-rata hasil belajar berjumlah 88 terjadi peningkatan $14.6 \%$ dibanding dengan data awal, berdasarkan pemaparan tersebut dapat disimpulkan bahwa penerapan metode pembelajaran examples non examples menggunakan media gambar dapat meningkatkan keterampilan menulis siswa kelas 2 SDN 022 Harapan Baru.

\section{Pembahasan}

Penelitian ini adalah penelitian tindakan kelas yang dilakukan di SDN 022 Harapan Baru Kecamatan Kempas Kabupaten Indragiri Hulu, tujuan penelitian ini adalah untuk meningkatkan keterampilan menulis siswa dengan menggunakan metode examples 
non examples dengan media gambar. Penggunaan metode examples non examples dengan media gambar bertujuan untuk mempermudah siswa dalam memahami topik pembelajaran karena dengan metode ini siswa akan mampu menganalisis suatu topik pembelajaran dengan melihat gambar secara langsung dan mampu menuangkan hasil analisis tersebut dalam bentuk tulisan sehingga dapat meningkatkan keterampilan menulis siswa. Penerapan metode pemebelajaran examples non examples dengan media gambar ini diberikan kepada siswa dengan melakukan pelatihan-pelatihan menulis terhadap siswa dengan menggunakan gambar sebagai media pembelajaran, karena dengan penggunaan gambar anak-anak akan lebih tertarik untuk belajar dan pembelajaran dikelas juga akan aktif dan komunikatif. Dengan penerapan metode ini dapat meningkatkan keterampilan menulis siswa.

Berdasarkan hasil penelitian data aktivitas guru saat pembelajaran mengalami peningkatan yang pada data awal hanya sebesar $55 \%$ dengan kategori cukup baik, kemudian pada pertemuan ke II didapat persentase sebesar $65 \%$ dengan kategori cukup baik, pada pertemuan ke III siklus II ditemukan data aktivitas guru sebesar $80 \%$ dengan kategori baik, pada pertemuan ke IV ditemukan data aktivitas guru sebesar $85 \%$ dengan kategori baik. Untuk hasil observasi aktivitas siswa pada siklus I pertemuan I didapat persentase aktivitas siswa dalam proses pembelajaran hanya sebesar $53 \%$ dengan kategori cukup baik, selanjutnya pada pertemuan ke II didapat persentase sebesar $60 \%$ dengan kategori cukup baik, kemudian pada siklus II pertemuan ke II didapat persentase sebesar $86 \%$ dengan kategori baik, dan pada pertemuan ke IV atau terakhir didapat persentase aktivitas belajar siswa sebanyak 92\% dengan kategori baik. Oleh karena itu dapat disimpulkan bahwa aktivitas siswa mengalami peningkatan yang signifikan dari data awal.
Untuk hasil belajar siswa atau keterampilan menulis siswa sebelum diberikan tindakan didapat nilai rata-rata hasil belajar siswa hanya sebesar 60 tentu saja nilai tersebut masih dibawah standar KKM , kemudian setelah dilakukan refleksi pembelajaran pada ulangan harian I didapat nilai rata-rata hasil belajar siswa berjumlah 80 terjadi peningkatan $13.3 \%$ dibanding dengan data awal, dan pada ulangan harian ke II nilai rata-rata hasil belajar siswa juga mengalami peningkatan dengan jumlah nilai rata-rata hasil belajar berjumlah 88 terjadi peningkatan $14.6 \%$ dibanding dengan data awal, berdasarkan pemaparan tersebut dapat disimpulkan bahwa penerapan metode pembelajaran examples non examples menggunakan media gambar dapat meningkatkan keterampilan menulis siswa kelas 2 SDN 022 Harapan Baru. Hal itu sesuai dengan pendapat Susanti (2014) mengatakan bahwa metode examples non examples menggunakan media gambar dapat meningkatkan keterampilan menulis siswa karena siswa dihadapkan dengan situasi yang nyata berupa gambar-gambar yang menarik sehingga siswa lebih mudah menganalisan dan menjelaskan suatu konsep dari gambar yang mereka amati tersebut sehingga dapat menjadi tulisan yang dapat dibaca sebagai informasi atau pengetahuan. Hal itu juga sejalan dengan pendapat Sulaiman (2018) menyimpulkan bahwa terdapat pengaruh penggunaan model pembelajaran examples non examples terhadap hasil belajar menulis. Penggunaan model pembelajaran examples non examples ini mampu meningkatkan hasil belajar menulis siswa.

\section{SIMPULAN}

Berdasarkan dari hasil dan pembahasan dapat disimpulkan bahwa penerapan metode examples non examples menggunakan media gambar dapat meningkatkan kemampuan menulis siwa kelas 2 SDN 022 Harapan Baru, dapat dilihat dari peningkatan aktivitas guru dan siswa saat pembelajaran serta peningkatan hasil belajar menulis siswa. Aktivitas guru saat 
pembelajaran mengalami peningkatan yang pada data awal hanya sebesar $55 \%$ dengan kategori cukup baik dan pada pertemuan ke IV data aktivitas guru sebesar $85 \%$ dengan kategori baik. Untuk hasil observasi aktivitas siswa pada siklus I pertemuan I didapat persentase aktivitas siswa dalam proses pembelajaran hanya sebesar $53 \%$ dengan kategori cukup baik dan pada pertemuan ke IV didapat persentase aktivitas belajar siswa sebanyak $92 \%$ dengan kategori baik. Untuk hasil belajar menulis siswa pada data awal nilai rata-rata hasil belajar siswa berjumlah 60 , kemudian setelah dilakukan refleksi pembelajaran pada ulangan harian I didapat nilai rata-rata hasil belajar siswa berjumlah 80 terjadi peningkatan $13,3 \%$ dibanding dengan data awal, dan pada ulangan harian ke II nilai rata-rata hasil belajar siswa juga mengalami peningkatan dengan jumlah nilai rata-rata hasil belajar berjumlah 88 terjadi peningkatan $14,6 \%$ dibanding dengan data awal, berdasarkan pemaparan tersebut dapat disimpulkan bahwa penerapan metode pembelajaran examples non examples menggunakan media gambar dapat meningkatkan keterampilan menulis siswa kelas 2 SDN 022 Harapan Baru.

\section{DAFTAR PUSTAKA}

Arikunto, S. (2014). Penelitian Tindakan Kelas. Jakarta: Rineka Cipta

Astuty, N. 2012. Penerapan Model Pembelajaran Kooperatif Tipe Examples non Examples Dengan Menggunakan Alat Peraga Untuk Meningkatkan Hasil Belajar Siswa di Kelas VIII. Jurnal Exacta, 10 (1).

Bukhari. (2010). Keterampilan Berbahasa Membaca dan Menulis. PeNA

Dewi, M. (2016). Meningkatkan Semangat Membaca Dan Menulis Siswa Sekolah Dasar Dengan Permainan Kata Bersambut. Jurnal Riset dan Konseptual, 1 (1), 39-42.

Febrina, L. (2017). Pegaruh Minat Baca Cerpen Terhadap Keterampilan
Menulis Cerpen Siswa Kelas X MAN. Jurnal Menara Ilmu, XI (74), 113-124. Lagandja. (2008). Meningkatkan Hasil Belajar Biologi Dengan menggunakan Model Pembelajaran Examples Non Examples Di SMA N 3 Gorontalo. Jurnal Penelitian dan Pendidikan, 5: 219- 229.

Martavia, R. F., Thahar, H. E., \& Asri, Y. (2016). Hubungan Minat Baca dengan Keterampilan Menulis Narasi Ekspositoris Siswa Kelas VII SMP Negeri 11 Padang. Jurnal Pendidikan Bahasa Dan Sastra Indonesia, 5(2), 363-369.

Nafiah, S. A. (2017). Model- Model Pembelajaran Bahasa Indonesia SD/MI. Ar Ruzz Media.

Pratiwi, D. A. P., Kristiantari, M. . R., \& Ganing, N. N. (2018). Hubungan Antara Minat Membaca Dengan Keterampilan Menulis Cerita Pendek Siswa Kelas V Sd Gugus Vii Mengwi Tahun Ajaran 2017/2018. Journal for Lesson and Learning Studies, 1(1), 4351.

https://doi.org/10.23887/jlls.v1i1.1462 $\underline{6}$

Windarto., H., K. (2020). Kajian keterampilan menulis menggunakan media gambar di sekolah dasar. Jurnal elementary school, 7(2), 303-311.

Hartati, T. (2006). Pendidikan Bahasa Indonesia dan Sastra Indonesia di Kelas Rendah. Bandung : UPI PRESS.

Hamdayama, J. (2014). Model dan Metode Pembelajaran Kreatif dan Berkarakter. Bogor: Ghalia Indonesia.

Huda, Miftahul. (2014). Model-Model Pengajaran dan Pembelajaran. Yogyakarta: Pustaka Pelajar.

Sobari, T. (2012). Penerapan Teknik Siklus Belajar Dalam Pembelajaran Menulis Laporan. Ilmiah Berbasis Vokasional. Sematik, 1(1), 17-41.

Sulaiman., A. (2018). Pengaruh penggunaan model pembelajaran examples non 
examples terhadap hasil belajar menulis teks berita pada siswa kelas VIII SMPN 14 Kota Tangerang. jurnal Penelitian Pendidikan Bahasa Indonesia, Daerah, dan Asing. 1 (2), 205-215.

Susanti. (2014). Pembelajaran Model Examples Non Examples Berbantuan Powerpoint Untuk Meningkatkan Hasil Belajar Ipa, JPII, 3 (2), 123127.

Sudijono, A (2004).Pengantar Statistik Pendidikan. Jakarta: Raja Grafindo

Setiawan, F., \& Mirnawati, L. B. (2017). Upaya Meningkatkan Keterampilan Menulis Karangan Siswa Kelas IV Sekolah Dasar Dengan Menggunakan Media Gambar Berseri. Prosiding Seminar Nasional Publikasi HasilHasil Penelitian Dan Pengabdian Masyarakat, September, 134-140. 